\title{
Trophic interactions between the 11 most abundant demersal fish species on the Pacific coast of central Mexico
}

\section{Interacciones tróficas de las 11 especies de peces demersales más abundantes en la costa central mexicana del Pacífico}

\author{
Juan Ramón Flores-Ortega ${ }^{1}$, Enrique Godínez-Domínguez ${ }^{2 *}$, Gaspar González-Sansón² \\ ${ }^{1}$ Laboratorio de Ecología Trófica, Escuela Nacional de Ingeniería Pesquera, Universidad Autónoma de \\ Nayarit, Apartado Postal no. 10, Bahía de Matanchén, km 12, CP 63740, San Blas, Nayarit, Mexico. \\ 2 Departamento de Estudios para el Desarrollo Sustentable de Zonas Costeras, Universidad de Guadalajara, \\ V Gómez Farías 82, CP 48980, San Patricio-Melaque, Jalisco, Mexico. \\ * Corresponding author. E-mail: egodinez@gmail.com
}

\begin{abstract}
We describe the diet, feeding strategy, and trophic interactions between the 11 most abundant demersal fish species on the Pacific coast of central Mexico during both the warm and cold seasons. A total of 4,547 stomachs were collected, with 1,921 empty stomachs being discarded. According to the stomach content analysis, 95 prey items were identified and grouped into 70 food categories belonging to crustaceans, mollusks, fish, polychaetes, and echinoderms. The Smith index value and high prey diversity indicated that the 11 fish species exhibited a generalist opportunistic feeding strategy in both survey seasons. Low values of dietary overlap were recorded, and only a few significant cases of dietary overlap were found in the interaction between some rays (Urotrygonidae) and flatfish species (Pleuronectiformes). The availability and abundance of prey resources in the environment and the generalization of niche breadth allows the demersal predator community of the soft shallow bottoms to coexist without any evident competition for trophic resources.
\end{abstract}

Key words: trophic interactions, demersal, fish, niche breadth, stomach contents.

RESUMEN. Se realizó la descripción de la dieta, la estrategia alimenticia y las interacciones tróficas de las 11 especies de peces demersales con mayor abundancia en la costa central mexicana del Pacífico durante 2 periodos, el cálido y el frío. En total se recolectaron 4,547 estómagos, de los cuales 1,921 estómagos vacíos fueron descartados. En el análisis de los contenidos estomacales fueron identificados 95 entidades alimentarias, que fueron agrupados en 70 categorías alimentarias pertenecientes a crustáceos, moluscos, peces, poliquetos y equinodermos. De acuerdo a los valores del índice de Smith y la alta diversidad de presas, la estrategia alimenticia mostrada por las 11 especies en ambas temporadas de estudio fue generalista-oportunista. Se registraron valores bajos en la superposición de la dieta y solamente se encontraron pocos casos significativos de superposición de la dieta en la interacción entre algunas especies de rayas de la familia Urotrygonidae y los lenguados del orden Pleuronectiformes. La disponibilidad y abundancia de recursos presa en el ambiente y la generalización de la amplitud del nicho permiten la coexistencia de la comunidad demersal de depredadores de fondos blandos someros sin competencia evidente por los recursos tróficos.

Palabras clave: interacciones tróficas, demersal, peces, amplitud de nicho, contenido estomacal.

\section{INTRODUCTION}

Soft bottoms concentrate a high diversity, richness, and abundance of fish and invertebrate species (Bianchi et al. 2000, Ruiz-Rodríguez et al. 2013). Benthic macrofauna contribute high percentages of energy to a system by recycling nutrients depositing from the pelagic zone and they are a food source for a large number of fishes that inhabit soft bottoms (Link et al. 2002).

The study of the ecological interactions of soft-bottom dwelling species contributes to the understanding of the structure, dynamics, and diversity of a community and the productivity of an ecosystem (Link et al. 2005, Dell et al. 2013). Fluctuations in the structure of benthic and demersal communities are caused by environmental variables (e.g., temperature, salinity, depth, etc.), the natural disturbance regime (Thrush et al. 1996, Godínez-Domínguez and Freire

\section{INTRODUCCIÓN}

En los fondos blandos se concentra una alta diversidad, riqueza y abundancia de peces e invertebrados (Bianchi et al. 2000, Ruiz-Rodríguez et al. 2013). La macrofauna bentónica aporta un alto porcentaje de energía al sistema a partir del reciclaje de nutrientes que se depositan desde la zona pelágica, y es la base alimentaria para una gran cantidad de peces que habitan los fondos blandos (Link et al. 2002).

El estudio de las interacciones ecológicas de las especies de fondos blandos contribuye a conocer la estructura, dinámica y diversidad de la comunidad, y la productividad del ecosistema (Link et al. 2005, Dell et al. 2013). Las fluctuaciones en la estructura de las comunidades bentónicas y demersales son provocadas por variables ambientales (e.g., temperatura, salinidad, profundidad, etc.) y el régimen natural de perturbaciones (Thrush et al. 1996, Godínez-Domínguez 
2003), and anthropogenic impacts (e.g., from pollution, changes to and development over the seafloor, and fishing) (Dell et al. 2013, Ruiz-Rodríguez et al. 2013). The main ecological interactions stem from the need to share a habitat and resources (Ross 1986). Changes in prey availability and abundance and in oceanographic conditions are some of the top factors affecting ecological and trophic interactions between species in marine environments (Rau et al. 2019).

The feeding strategies of fish inhabiting soft bottoms are a result of morphological and physiological adaptations and temporal variability of food resources (Espinoza et al. 2013, Flores-Ortega et al. 2014). The evolution of species has been key for adapting to drastic changes in the availability and abundance of trophic resources (Lucena et al. 2000, Carrassón and Cartes 2002), hence the emergence of strategies that prevent species from competing for resources (habitat and food) with other organisms, and these strategies are important in understanding the shared use of resources in soft-bottom habitats (Lucena et al. 2000, Moura et al. 2008).

On the Pacific coast of central Mexico (PCCM), studies on the trophic interactions between demersal fish species are scarce (Pérez-España et al. 2005; Aguilar-Palomino and González-Sansón 2010; Flores-Ortega et al. 2011, 2013) because research has focused on describing the diet composition of, almost always, one species at a time. The present study is the first to analyze the trophic interactions in a group of 11 species comprising the bulk of abundance and biomass in the community of soft-bottom demersal fish in the PCCM; the study also determines trophic niche breadth, the degree of dietary overlap, and the patterns of similarity in the associations of prey making up the diet of the fishes and the seasonal variation of these interactions.

\section{MATERIALS AND METHOdS}

\section{Study area}

The study area is located on the southernmost limit of the coast of the state of Jalisco, in the PCCM, from Coco Beach to Chamela Bay (Fig. 1). A conspicuous seasonal hydroclimatic cycle prevails in this region, which influences benthic and demersal environments (Godínez-Domínguez et al. 2009). During the intense upwelling period - cold periodwhich spans from February to May, high chlorophyll $a$ concentrations and primary productivity rates predominate; this period is followed by a period of transition and upwelling relaxation (June). During July to November-warm periodthe water column stratifies and chlorophyll $a$ concentrations drop, as do primary productivity rates (López-Sandoval et al. 2009a, b). In general, the hydroclimatic seasonality pattern changes coastal processes (Filonov et al. 2000, Kessler 2006) and determines the recomposition of coastal fish communities (Godínez-Domínguez et al. 2000) and soft-bottom benthic macroinvertebrates (Godínez-Domínguez et al. 2009). y Freire 2003), además de los impactos antropogénicos (e.g., de la contaminación, la modificación de y construcción sobre los fondos marinos, y la pesca) (Dell et al. 2013, Ruiz-Rodríguez et al. 2013). Las principales interacciones ecológicas se originan de la necesidad de compartir el hábitat y los recursos (Ross 1986). Los cambios en la disponibilidad y abundancia de las presas, así como de las condiciones oceanográficas, son de los principales factores que afectan las interacciones ecológicas y tróficas entre las especies en los ambientes marinos (Rau et al. 2019).

Las estrategias alimentarias de los peces en los fondos blandos son el resultado de las adaptaciones morfológicas y fisiológicas y la variabilidad temporal de los recursos alimentarios (Espinoza et al. 2013, Flores-Ortega et al. 2014). La evolución de las especies ha sido clave para la adaptación a cambios drásticos en la disponibilidad y abundancia de los recursos tróficos (Lucena et al. 2000, Carrassón y Cartes 2002), de ahí el surgimiento de estrategias que les permite evitar la competencia por los recursos (hábitat y alimento) con otros organismos, estrategias que son importantes para comprender el uso compartido de los recursos en los hábitats de fondos blandos (Lucena et al. 2000, Moura et al. 2008).

En la costa central mexicana del Pacífico (CCMP), los estudios sobre las interacciones tróficas entre las especies de peces demersales son escasos (Pérez-España et al. 2005; Aguilar-Palomino y González-Sansón 2010; Flores-Ortega et al. 2011, 2013), ya que las investigaciones se han centrado en describir la composición de la dieta, casi siempre de una especie a la vez. En el presente trabajo se realiza, por primera vez, un análisis de las interacciones tróficas en un grupo de 11 especies que representa la mayoría de la abundancia y biomasa de la comunidad de peces demersales de fondos blandos en la CCMP, y se determina la amplitud del nicho trófico, el grado de superposición de la dieta y los patrones de similitud en la composición de las asociaciones de presas que conforman la dieta de los peces y la variación estacional de dichas interacciones.

\section{MATERIALES Y MÉTODOS}

\section{Área de estudio}

El área de estudio está localizada en el extremo sur de la costa del estado de Jalisco, en la CCMP, desde la playa el Coco hasta la bahía de Chamela (Fig. 1). En esta región prevalece un ciclo estacional hidroclimático conspicuo, que influye en ambientes bentónicos y demersales (Godínez-Domínguez et al. 2009). Durante el periodo de afloramiento intenso - periodo frío- que va de febrero a mayo, predominan altas concentraciones de clorofila $a \mathrm{y}$ altas tasas de productividad primaria, y este periodo es seguido de un periodo de transición y de relajación de las surgencias (junio). Durante julio a noviembre - periodo cálido- se presentan condiciones de estratificación de la columna de agua, y las concentraciones de clorofila 


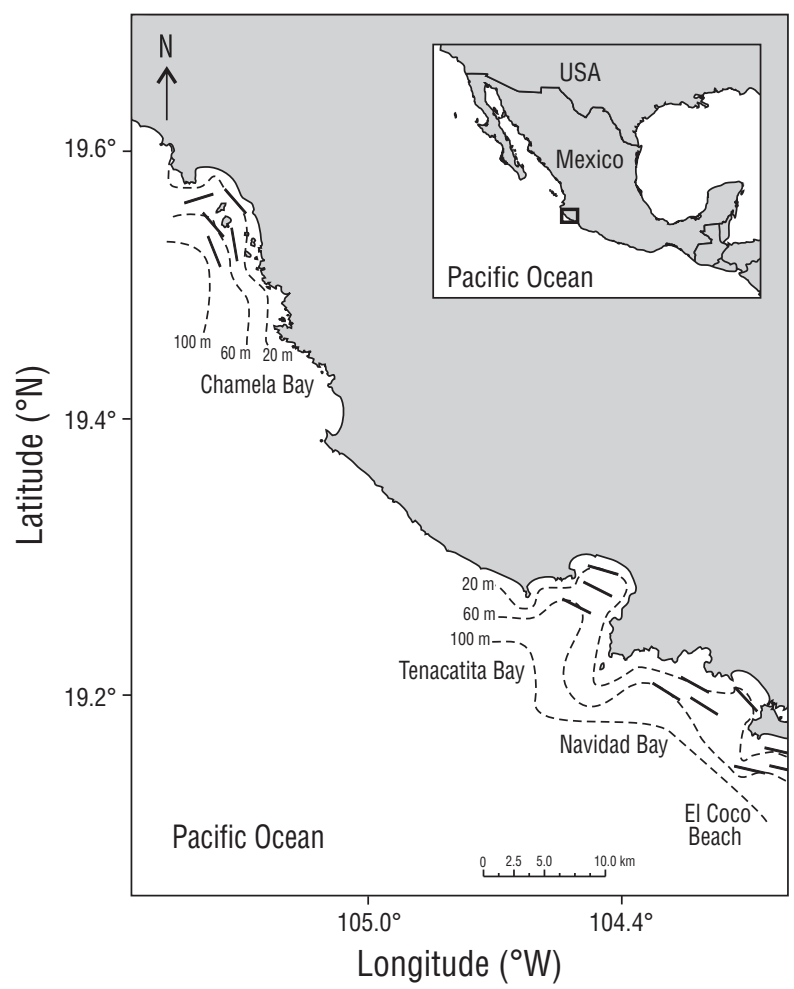

Figure 1. Study area. The short solid lines indicate the sampling trawls and the dashed lines the isobaths (m).

Figura 1. Área de estudio. Las líneas continuas cortas indican los sitios de arrastre de pesca y las líneas punteadas las isobatas (m).

\section{Sampling and sample collection}

Between October 2007 and May 2010, 67 trawls were carried out on board the vessel BIP $V$ at 4 sampling sites (Coco Beach, Navidad Bay, Tenacatita Bay, and Chamela Bay). The trawls were done at night for 30 min using 2 trawl nets (one on each side of the vessel) similar to those used in commercial shrimp fishing on the Pacific coast of Mexico, with mouth width of $6.9 \mathrm{~m}$ and mesh size of $38 \mathrm{~mm}$ at the codend. Fishes were separated from the rest of the catch for taxonomic identification at the species level. For each captured specimen, total length $(\mathrm{cm})$ and total weight $(\mathrm{g})$ were recorded and dissection was made to extract the stomach, which was frozen $\left(-4{ }^{\circ} \mathrm{C}\right)$ for subsequent analysis in the laboratory. Fish stomachs were grouped by species and season (cold from January to June and warm from July to December). The organisms found in each stomach were identified down to the lowest possible taxon with the help of specialized keys for each group, and prey items were counted and weighed on an Acculab Vicon precision electronic scale (0.001 g precision). To determine the sufficiency of the number of analyzed stomachs, cumulative prey curves were created and the Shannon-Wiener diversity index was calculated for each species, resampling for rarefaction with 100 randomizations in EstimateS 8.2 (Colwell 2013). Sample sufficiency $a$ bajan, al igual que las tasas de productividad primaria (López-Sandoval et al. 2009a, b). De manera general, el patrón de estacionalidad hidroclimático produce cambios en los procesos costeros (Filonov et al. 2000, Kessler 2006) y determina la recomposición de las comunidades de peces costeros (Godínez-Domínguez et al. 2000) y macroinvertebrados bentónicos de fondos blandos (Godínez-Domínguez et al. 2009).

\section{Muestreos y obtención de muestras}

Se realizaron 67 arrastres entre octubre de 2007 y mayo de 2010 a bordo del barco BIP $V$ en 4 sitios de muestreo (playa el Coco, bahía de Navidad, bahía de Tenacatita y bahía de Chamela). Los arrastres se realizaron por la noche, con una duración de $30 \mathrm{~min}$, y fueron utilizadas 2 redes de arrastre (una de cada lado de la embarcación) similares a las empleadas en la pesca comercial de camarón en la costa mexicana del Pacífico, con $6.9 \mathrm{~m}$ de ancho de boca y $38 \mathrm{~mm}$ de luz de malla en el copo. Los peces fueron separados del resto de la captura para ser identificados taxonómicamente al nivel especie. De cada ejemplar capturado, se registró la longitud total $(\mathrm{cm})$ y el peso total $(\mathrm{g})$ y se hizo una disección para extraer el estómago y congelarlo $\left(-4{ }^{\circ} \mathrm{C}\right)$ para su posterior análisis en el laboratorio. Los estómagos de los peces fueron agrupados por especie y época de año (época fría) de enero a junio y época cálida de julio a diciembre). Los organismos encontrados dentro de cada estómago se identificaron hasta el taxón más bajo posible con la ayuda de claves especializadas para cada grupo, y las entidades alimentarias fueron contabilizadas y pesadas en una balanza electrónica de precisión Acculab Vicon (0.001 g de precisión). Para determinar la suficiencia del número de estómagos analizados, se generaron curvas de acumulación de las entidades alimentarias y se calculó el índice de diversidad de Shannon-Wiener para cada una de las especies, por medio de un procedimiento de remuestreo con 100 aleatorizaciones en el programa EstimateS 8.2 (Colwell 2013). Se considera que se logra la suficiencia de muestras si visualmente las curvas de diversidad alcanzan un comportamiento asintótico (Magurran 2004).

\section{Análisis del contenido estomacal}

Los componentes alimentarios encontrados en los estómagos se cuantificaron de acuerdo a los métodos numérico, gravimétrico y frecuencia de ocurrencia. Se estimó el índice de Smith (Smith 1982) para conocer la amplitud del nicho trófico y la estrategia alimentaria de cada una de las especies. Como medida de la competencia potencial entre las especies de peces, se utilizó el índice de Pianka (Pianka 1973), el cual estima la superposición de dietas. La superposición de la dieta entre 2 especies con valor mayor que 0.60 es considerada alta (Langton 1982). Ambos índices están estandarizados entre 0 y 1 (Krebs 1999), y los cálculos se realizaron con el programa Ecological Methodology 7.0. Se analizó la 
is considered to be achieved if the diversity curves visually reach an asymptote (Magurran 2004).

\section{Stomach content analysis}

The food components in the stomachs were quantified according to the numerical, gravimetric, and frequency of occurrence methods. The Smith index (Smith 1982) was estimated to find the breadth of the trophic niche and the feeding strategy of each species. The Pianka index (Pianka 1973), which yields dietary overlap, was used to measure potential competition between fish species. A dietary overlap between 2 species showing a value greater than 0.60 is considered high (Langton 1982). Both indices are standardized between 0 and 1 (Krebs 1999), and calculations were made using Ecological Methodology 7.0. Species richness in predator diets between seasons was analyzed using iNEXT (Hsieh et al. 2016) in $\mathrm{R}$ language ( $\mathrm{R}$ Core Team 2019), according to Chao et al. (2014) for cases of unbalanced designs and with different numbers of stomachs analyzed. Estimates of species richness (order $\mathrm{q}=0$ ) in the diet and the respective $95 \%$ confidence intervals from rarefaction curves were determined considering the lowest number of organisms found in the diet of a predator $(n=30)$, which allows for robust comparisons of diets between hydroclimatic periods (Chao et al. 2014).

The non-metric multidimensional scaling method was used (Clarke 1993) to graphically analyze predator association patterns using prey composition by species and by season. The Bray-Curtis index (Clarke and Warwick 2001) was used to measure similarity, and it was estimated with the values of percent weight $(\% \mathrm{~W})$ each food category contributed to the diet. Diet similarity for each species was comparatively analyzed between hydroclimatic periods with a one-way similarity analysis (Clarke and Warwick 2001).

\section{RESULTS}

\section{Overall description of diets}

For the stomach content analysis, a total of 4,547 stomachs, of which 2,626 (57.8\%) had content and 1,921 (42.2\%) were empty, were extracted from the 11 most abundant species in the PCCM. Of the total number of stomachs with contents, 1,453 corresponded to samples from the warm season and 1,173 to samples from the cold season (Table 1). Since Cyclopsetta querna were vastly abundant, we decided to separate the analysis of the diet of juveniles and adults.

The food source of the 11 demersal fish species comprised 95 prey items, which were grouped into 70 food categories for the analysis of trophic interactions and associations (Table 2). The total number of stomachs with content analyzed for each species was considered adequate to describe the diet of the 11 demersal fish species because the cumulative curves tended toward an asymptote (Fig. 2). riqueza de especies en las dietas de los depredadores entre temporadas, por medio del programa iNEXT (Hsieh et al. 2016) en lenguaje $R$ ( $R$ Core Team 2019), de acuerdo con Chao et al. (2014) para los casos de diseño no balanceado y con diferente número de estómagos analizados. Los estimados de riqueza de especies (orden $\mathrm{q}=0$ ) en la dieta $\mathrm{y}$ los respectivos intervalos de confianza al $95 \%$ por curvas de rarefacción, se determinaron considerando el valor menor de organismos encontrados $(n=30)$ en la dieta de un depredador, lo cual permite una comparación robusta de la dieta entre periodos hidroclimáticos (Chao et al. 2014).

Para analizar gráficamente el patrón de asociación de depredadores con base en la composición de las presas de acuerdo a la especie y temporada de estudio, se utilizó el método de escalado multidimensional no métrico (Clarke 1993). Se utilizó el índice de Bray-Curtis (Clarke y Warwick 2001) como medida de similitud, y este fue estimado con los valores porcentuales de peso $(\% \mathrm{~W})$ que las categorías alimentarias contribuyeron en la dieta. Se analizó comparativamente la similitud de la dieta para cada especie entre periodos hidroclimáticos mediante un análisis de similitud de una vía (Clarke y Warwick 2001).

\section{Resultados}

\section{Descripción general de las dietas}

Para el análisis de contenido estomacal, fueron recolectados 4,547 estómagos de las 11 especies más abundantes en la CCMP, de los cuales 2,626 (57.8\%) presentaron contenido y $1,921(42.2 \%)$ estaban vacíos. Del número total de estómagos con contenido, 1,453 correspondieron a muestras de la época cálida y 1,173 a muestras de la época fría (Tabla 1). Debido a la gran abundancia de juveniles de Cyclopsetta querna, se optó por separar el análisis de la dieta de los juveniles y los adultos.

La base alimentaria de las 11 especies de peces demersales estuvo conformada por 95 entidades alimentarias, las cuales fueron agrupadas en 70 categorías alimentarias para los análisis de las interacciones y asociaciones tróficas (Tabla 2). El número total de estómagos con contenido analizados para cada especie se consideró adecuado para describir la dieta de las 11 especies de peces demersales, ya que las curvas acumuladas mostraron una tendencia hacia la asíntota (Fig. 2).

\section{Descripción de las dietas por especie}

\section{Bothus leopardinus}

Se analizaron 579 estómagos, de los cuales solo 262 presentaron contenido (Tabla 1). La dieta estuvo compuesta de 27 categorías alimentarias: 17 de crustáceos, 3 de moluscos, 3 de peces, 3 de poliquetos y 1 de restos de una anemona. Los principales componentes, según los valores de $\% \mathrm{~W}$, fueron los crustáceos, seguido de los peces: Penaeidae (16.0\%), 


\section{Description of the diets by species}

\section{Bothus leopardinus}

Of the 579 analyzed stomachs, only 262 had contents (Table 1). The diet was made up of 27 food categories: 17 crustaceans, 3 mollusks, 3 fishes, 3 polychaetes, and 1 of remains of an anemone. The main components, according to the $\% \mathrm{~W}$ values, were crustaceans, followed by fishes: Penaeidae (16.0\%), Portunidae (11.5\%), Alpheidae (8.3\%), Brachyura larvae $(6.9 \%)$, and fishes $(\sim 22.0 \%)$, particularly of the family Paralichthydae $(9.5 \%)$ (Table 2$)$.

\section{Cyclopsetta querna (juveniles)}

In total 323 organisms were analyzed, but only 119 had contents (Table 1). For this species, 23 food categories were identified: 10 crustaceans, 4 mollusks, and 7 fishes, polychaetes, and unidentified eggs. Fishes $(\sim 80.0 \%)$ were the main food category in the diet (Table 2).

\section{Cyclopsetta querna (adults)}

A total of 95 stomachs were analyzed, of which only the 73 that had contents were considered (Table 1). The diet consisted of 5 categories of fishes, 8 of crustaceans, and only 1 of mollusks and 1 of polychaetes. The most important categories were fishes $(\sim 55.0 \%)$ and loliginid squids $(38.3 \%)$ (Table 2$)$.
Portunidae (11.5\%), Alpheidae (8.3\%), larvas de Brachyura $(6.9 \%)$ y peces $(22.0 \%)$, en particular de la familia Paralichthydae $(9.5 \%)$ (Tabla 2$)$.

\section{Cyclopsetta querna (juveniles)}

En total se analizaron 323 organismos, pero solo 119 presentaron contenido (Tabla 1). Se identificaron 23 categorías alimentarias: 10 de crustáceos, 4 de moluscos y 7 de peces, poliquetos y huevos no identificados. Los peces $(\sim 80.0 \%)$ fueron la principal categoría alimentaria en la dieta (Tabla 2).

\section{Cyclopsetta querna (adultos)}

Se analizaron en total 95 estómagos, de los cuales solo se consideraron los 73 que presentaron contenido (Tabla 1). La dieta estuvo conformada por 5 categorías de peces, 8 de crustáceos y solo 1 de moluscos y 1 de poliquetos. Las categorías de mayor importancia fueron los peces $(\sim 55.0 \%)$ y los calamares loligínidos (38.3\%) (Tabla 2).

\section{Diodon holocanthus}

Se recolectaron un total de 391 estómagos, pero solo en 307 se encontraron categorías alimentarias (Tabla 1). Se identificaron en total 47 categorías alimentarias. Los moluscos fueron el grupo con el mayor número de categorías (22); sin embargo, las principales categorías alimentarias fueron

Table 1. Main demersal fish species caught on the Pacific coast of central Mexico and number of analyzed stomachs in total (Nt) and with contents $(\mathrm{Nc})$ by sampling season, fish size, and trawling depth range at which $90 \%$ of the individuals were caught.

Tabla 1. Principales especies de peces demersales capturadas en la costa central mexicana del Pacífico y número de estómagos analizados en total $(\mathrm{Nt})$ y con contenido $(\mathrm{Nc})$ para cada temporada de estudio, talla de los peces e intervalo de profundidad a la que fueron capturados el $90 \%$ de los organismos.

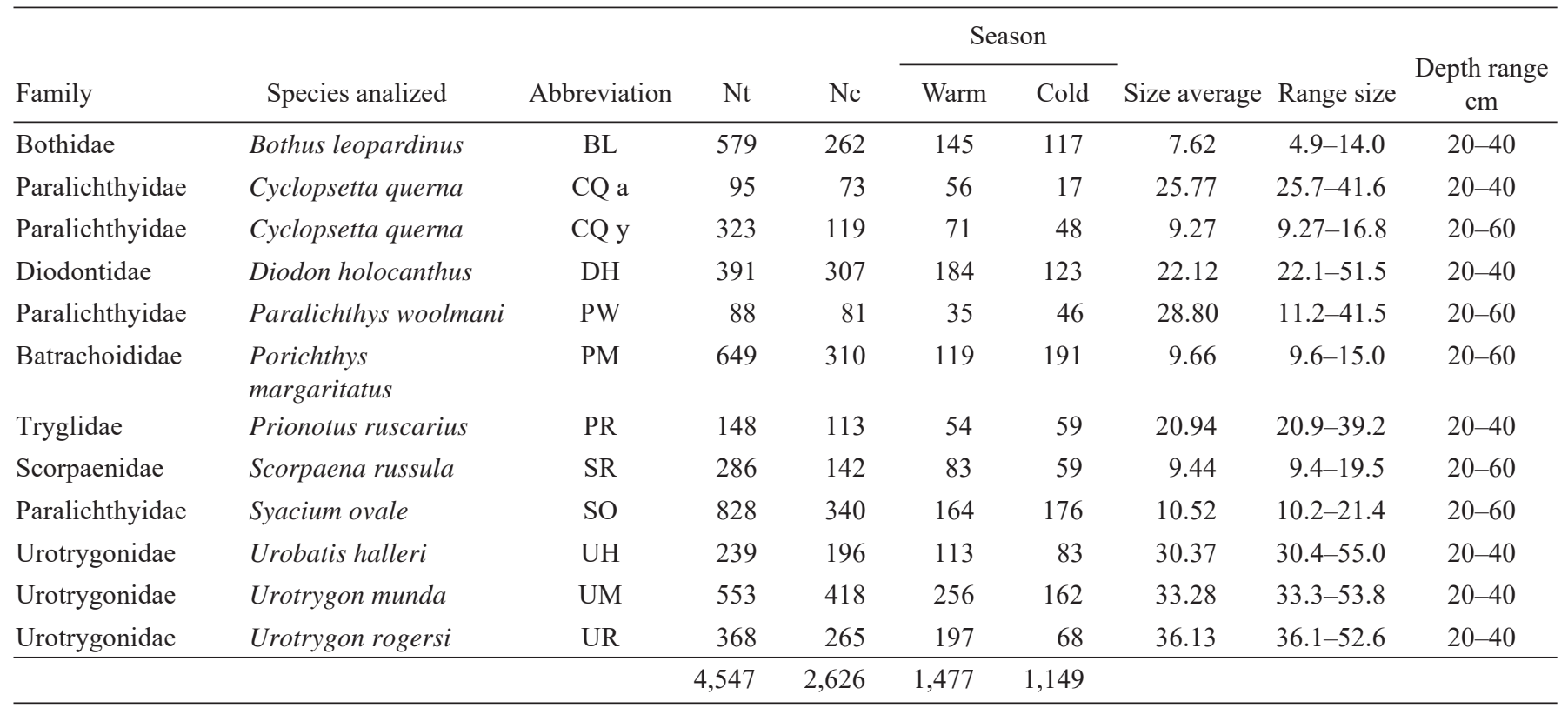


Ciencias Marinas, Vol. 46, No. 2, 2020

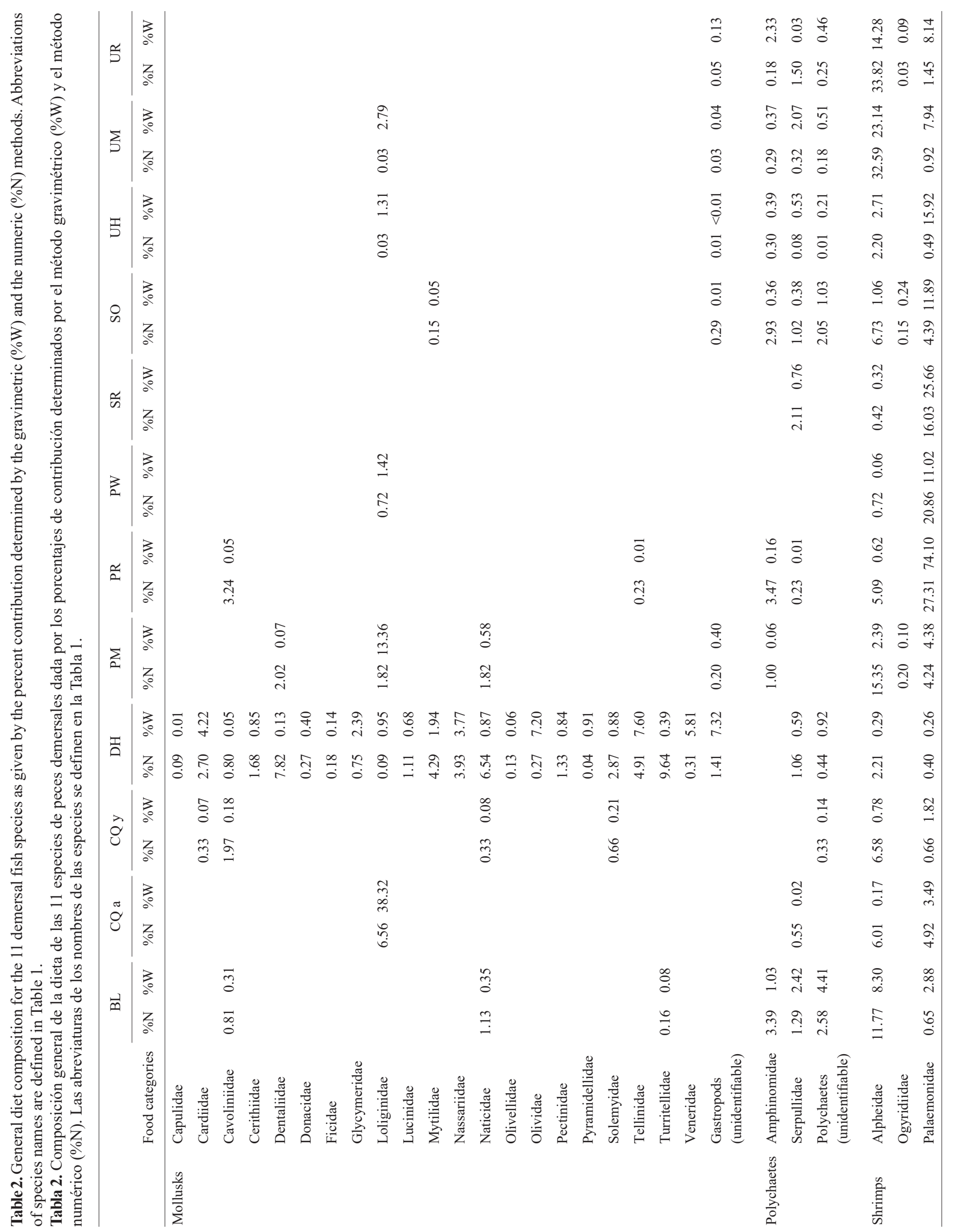




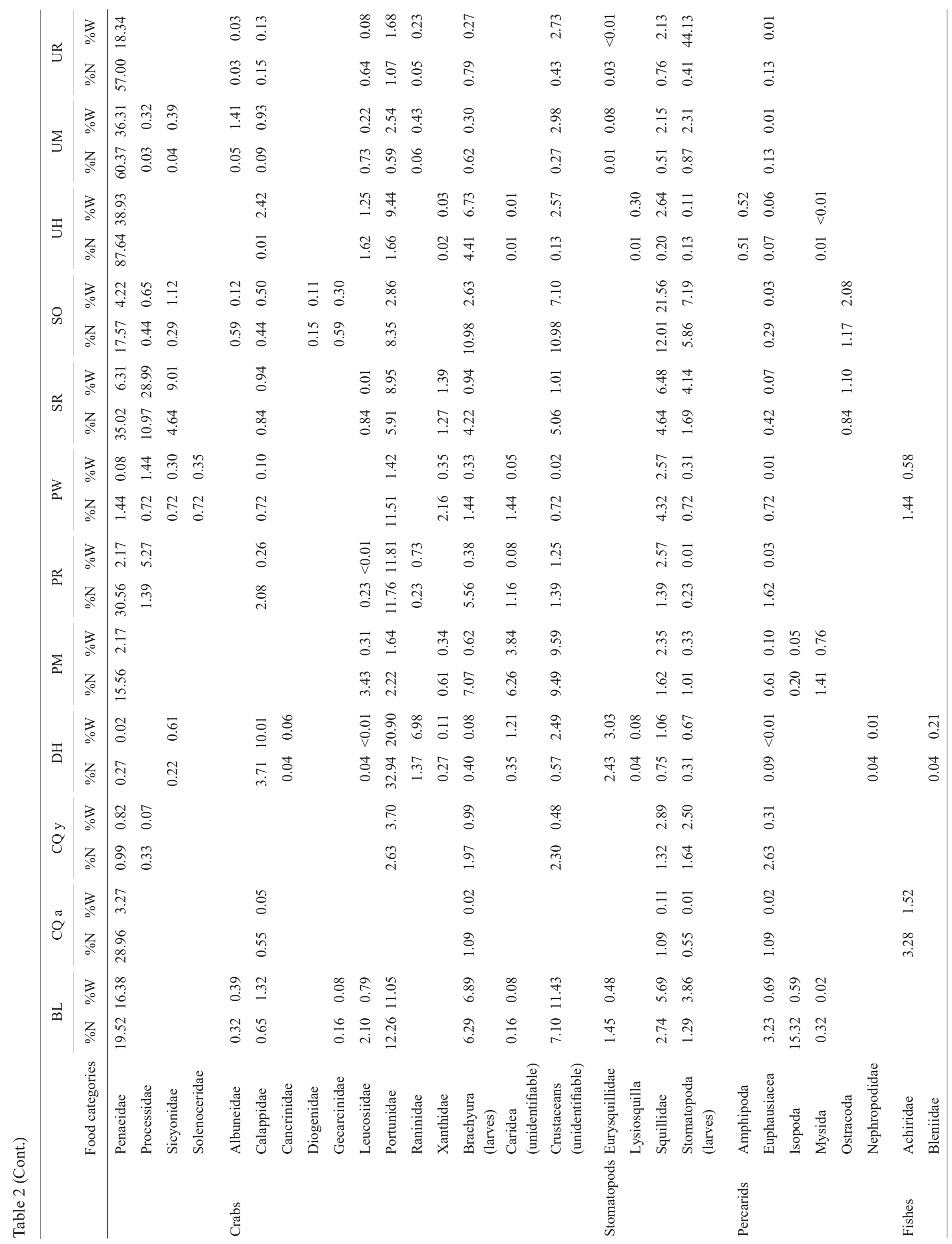




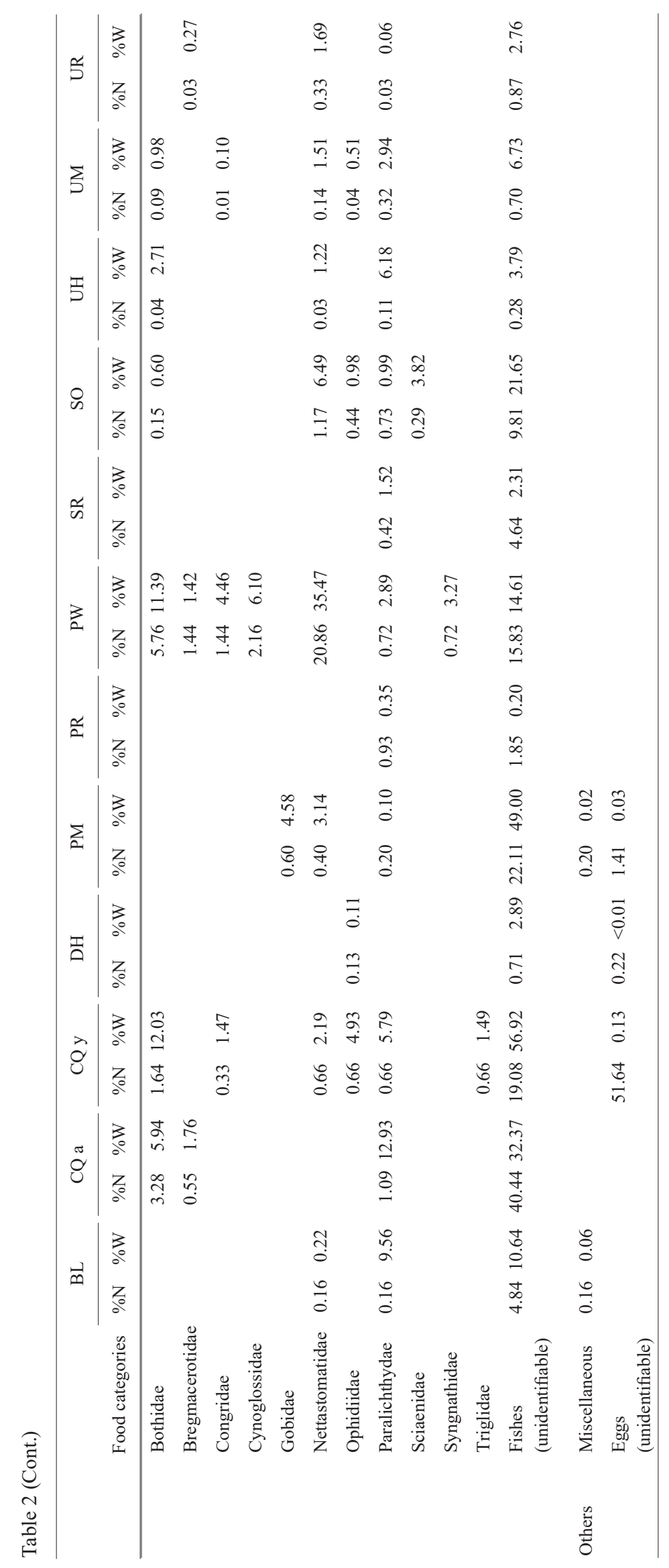




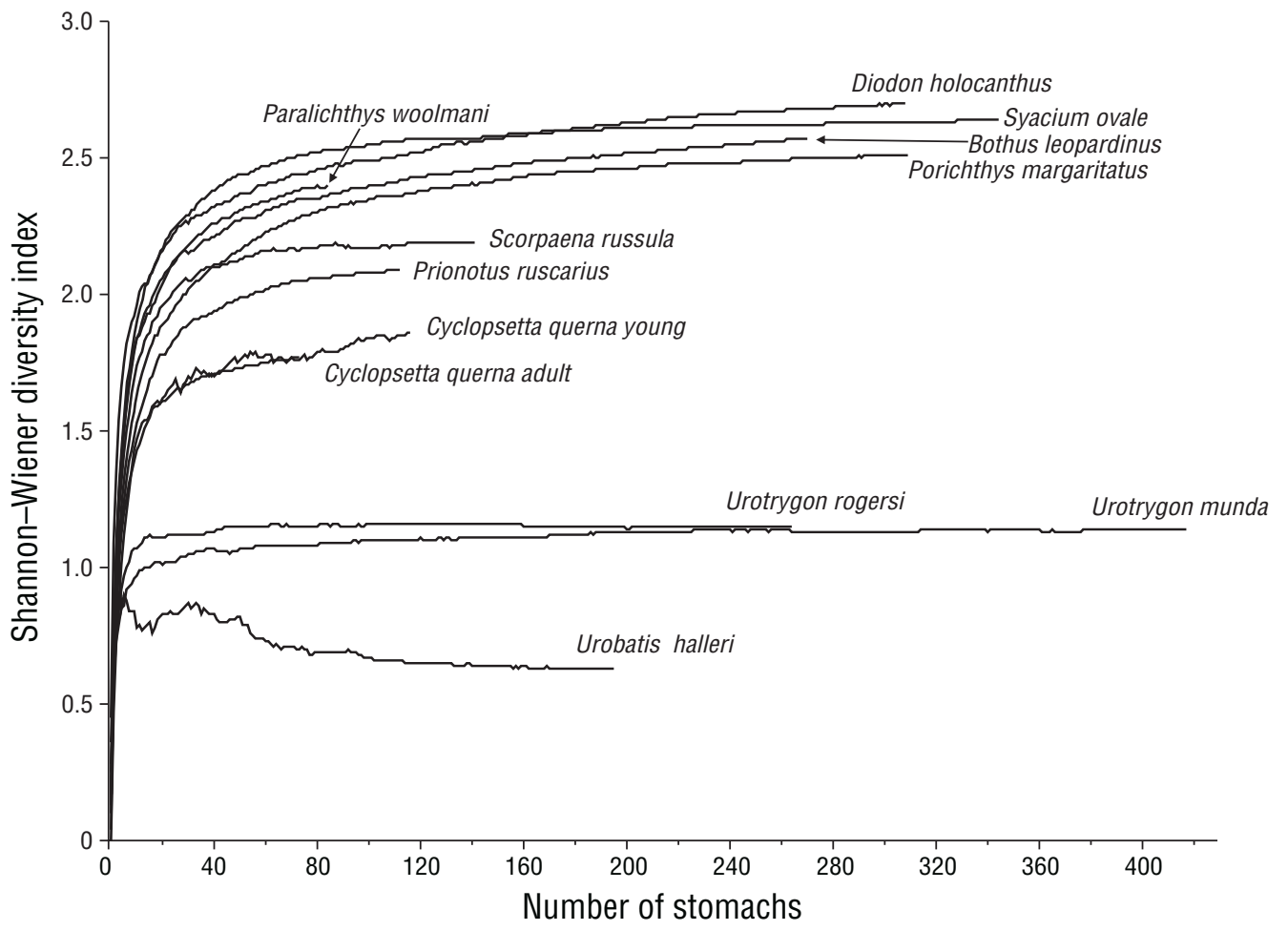

Figure 2. Cumulative mean Shannon-Wiener diversity index for prey found in the stomachs of the 11 demersal fish species.

Figura 2. Curvas acumuladas con los valores promedio del índice de diversidad de Shannon-Wiener para las presas encontradas en los estómagos de las 11 especies de peces demersales.

\section{Diodon holocanthus}

A total of 391 stomachs were collected, but food categories were found in only 307 stomachs (Table 1). A total of 47 food categories were identified. Mollusks were the group with the highest number of food categories (22); however, the main food categories were portunid crabs $(21.0 \%)$, calapid crabs $(10.0 \%)$, and mollusks ( $49.0 \%)$, particularly Tellinidae (7.6\%) and Olividae (7.2\%) bivalves (Table 2).

\section{Paralichthys woolmani}

A total of 25 food categories were identified in 81 of the 88 stomachs analyzed (Table 1$)$. Fishes $(\sim 80.0 \%)$ and Palemonidae shrimps $(11.0 \%)$ were the main prey in the diet (Table 2).

\section{Porichthys margaritatus}

A total of 26 food categories were identified in 310 of the 649 stomachs analyzed (Table 1). The group of crustaceans had the highest number of food categories (15), followed by the mollusks and fishes (4), the polychaetes (1), and the unidentified anemones and eggs (1). Fishes $(\sim 56.0 \%)$, crustaceans $(\sim 27.0 \%)$, and loliginid squids $(13.3 \%)$ were conspicuous among the prey (Table 2). los cangrejos portúnidos (21.0\%), los cangrejos calápidos (10.0\%), y los moluscos ( 49.0\%), en particular los bivalvos Tellinidae (7.6\%) y Olividae (7.2\%) (Tabla 2 ).

\section{Paralichthys woolmani}

Se identificaron 25 categorías alimentarias en 81 de los 88 estómagos analizados (Tabla 1$)$. Los peces $(\sim 80.0 \%)$ y los camarones Palemonidae (11.0\%) fueron las principales presas en la dieta (Tabla 2).

\section{Porichthys margaritatus}

Se identificaron 26 categorías alimentarias en 310 de los 649 estómagos analizados (Tabla 1). El grupo de los crustáceos presentó el mayor número de categorías alimentarias (15), seguido del grupo de los moluscos y peces (4), el grupo de los poliquetos (1) y el grupo de anemonas y huevos no identificados (1). Destacaron entre las presas los peces $(\sim 56.0 \%)$, los crustáceos $(\sim 27.0 \%)$ y los calamares loligínidos (13.3\%) (Tabla 2).

\section{Prionotus ruscarius}

Se analizaron en total 148 estómagos, de los cuales solo 113 presentaron contenido (Tabla 1). Se identificaron 20 


\section{Prionotus ruscarius}

A total of 148 stomachs were analyzed, of which only 113 had content (Table 1). A total of 20 food categories were identified: 14 crustaceans, 2 mollusks, 2 fishes, and 2 polychaetes. Palaemonidae shrimps $(74.0 \%)$ were the main prey, followed by portunid crabs (12.0\%) (Table 2).

\section{Scorpaena russula}

In total 286 stomachs were analyzed, of which only 142 had content (Table 1). A total 18 food categories were identified: 15 crustaceans, 2 fishes, and 1 polychaete. The main prey were Processidae (29.0\%), Palaemonidae (26.0\%), and Sicyonidae (9.0\%) shrimps and Portunidae crabs $(9.0 \%)$ (Table 2).

\section{Syacium ovale}

To describe the diet of this species, 828 stomachs were analyzed but only 340 stomachs had content (Table 1). In total, 28 food categories were identified in the diet. Fishes ( $\sim 35.0 \%)$, stomatopods $(\sim 30.0 \%)$, and Palaemonidae shrimps $(12.0 \%)$ were the main components in the diet (Table 2 ).

\section{Urobatis halleri}

In total 239 stomachs were analyzed but only 196 had content (Table 1). The food categories in the group of crustaceans were the most important in the diet (16), followed by the fishes (4), the polychaetes (3), and the mollusks (2). The main components in the diet were Penaeidae (39.0\%) and Palaemonidae (16.0\%) shrimps, portunid crabs $(9.5 \%)$, and brachyurus larvae $(6.7 \%)$ (Table 2$)$.

\section{Urotrygon munda}

A total of 553 stomachs were analyzed, of which only 418 had content (Table 1). Twenty-seven food categories were identified in the diet, of which crustaceans had the highest presence (16), followed by fishes (6), polychaetes (3), and mollusks (2). Shrimp of the Penaeidae (36.3\%), Palaemonidae (8.0\%), and Alpheidae (23.1\%) families, and fishes $(13.0 \%)$ showed the greatest contribution to the diet (Table 2).

\section{Urotrygon rogersi}

To describe the diet, 368 stomachs were collected but only 265 had content (Table 1). A total of 23 food categories were identified: 15 crustaceans, 4 fishes, 3 polychaetes, and 1 mollusk. The main food categories were stomatopod larvae (44.0\%) and shrimps from the Penaeidae (18.3\%), Alpheidae (14.3\%), and Palaemonidae (8.1\%) families (Table 2). categorías alimentarias: 14 de crustáceos, 2 de moluscos, 2 de peces y 2 de poliquetos. Los camarones Palaemonidae (74.0\%) fueron la principal presa alimentaria, y en segundo término estuvieron los cangrejos portúnidos (12.0\%) (Tabla 2).

\section{Scorpaena russula}

En total se analizaron 286 estómagos, de los cuales solo 142 presentaron contenido (Tabla 1). Se identificaron 18 categorías alimentarias: 15 de crustáceos, 2 de peces y 1 de poliqueto. Los camarones Processidae (29.0\%), Palaemonidae $(26.0 \%)$ y Sicyonidae $(9.0 \%)$, y los cangrejos Portunidae $(9.0 \%)$ fueron las principales presas (Tabla 2 ).

\section{Syacium ovale}

Se analizaron 828 estómagos para describir la dieta de esta especie, pero solo 340 estómagos presentaron contenido (Tabla 1). Se identificaron 28 categorías alimentarias en la dieta. Los peces $(\sim 35.0 \%)$, los estomatópodos $(\sim 30.0 \%)$ y los camarones Palaemonidae (12.0\%) fueron las principales componentes en la dieta (Tabla 2).

\section{Urobatis halleri}

Fueron analizados 239 estómagos, pero solo 196 presentaron contenido (Tabla 1). Las categorías alimentarias del grupo de los crustáceos fueron las de mayor importancia en la dieta (16), seguido del grupo de los peces (4), el grupo de los poliquetos (3) y el grupo de los moluscos (2). Los camarones Penaeidae (39.0\%) y Palaemonidae (16.0\%), los cangrejos portúnidos $(9.5 \%)$ y las larvas de braquiuros $(6.7 \%)$ fueron las principales componentes en la dieta (Tabla 2).

\section{Urotrygon munda}

Un total de 553 estómagos fueron analizados, de los cuales solo 418 presentaron contenido (Tabla 1). Se identificaron 27 categorías alimentarias en la dieta, de las cuales los crustáceos fueron las de mayor presencia (16), seguido de los peces (6), los poliquetos (3) y los moluscos (2). Los camarones de las familias Penaeidae (36.3\%), Palaemonidae $(8.0 \%)$ y Alpheidae (23.1\%), y los peces (13.0\%) presentaron la mayor contribución a la dieta (Tabla 2).

\section{Urotrygon rogersi}

Se recolectaron 368 estómagos para describir la dieta, pero solo 265 presentaron contenido (Tabla 1). Se identificaron 23 categorías alimentarias: 15 de crustáceos, 4 de peces, 3 de poliquetos y 1 de moluscos. Las principales categorías alimentarias fueron las larvas de estomatópodos (44.0\%) y los camarones de las familias Penaeidae (18.3\%), Alpheidae (14.3\%) y Palaemonidae (8.1\%) (Tabla 2). 


\section{Trophic niche breadth, overlapping diets}

Smith index values showed a broad trophic niche (FT > 0.5 ) for all species in both seasons. They all consumed a high number of prey and showed a generalist feeding strategy, allowing them to consume any type of available prey. In the summer values ranged between 0.6 and 0.8 , and during the winter the values varied between 0.5 and 0.8 (Fig. 3).

In general, the Pianka index showed low values in the dietary overlap between the fish species analyzed. High values in dietary overlap were found between Pleuronectiformes flatfishes and ray species of the Urotrygonidae family (Table 3). In the warm season there were 6 interactions with high values of dietary overlap: $C$. querna juveniles with $P$. margaritatus (0.79), C. querna with $S$. ovale (0.82), P. margaritatus with S. ovale (0.79), U. halleri with $U$. munda (0.92), $U$. halleri with $U$. rogersi $(0.86)$, and $U$. munda with $U$. rogersi $(0.95)$. For the cold season, dietary overlap values were high for interactions of $B$. leopardinus with $U$. munda (0.77), B. leopardinus with U. rogersi (0.77), C. querna juveniles with P. margaritatus (0.82), P. ruscarius with S. russula (0.99), P. ruscarius with $U$. rogersi $(0.70)$, and $U$. munda with $U$. rogersi (0.94). According to the values of expected prey richness (Fig. 4), 3 groups were formed: (a) diet with high species richness composed of $D$. holocanthus, P. woolmani, S. ovale, P. margaritatus, and B. leopardinus; (b) diet with intermediate richness composed of $P$. ruscarius, S. russula, and adults and juveniles of C. querna; and (c) diet with low species richness composed of $U$. halleri, $U$. munda, and $U$. rogersi. The species that showed changes in species richness in their diets between seasons were $D$. holocanthus, B. leopardinus, P. ruscarius, and U. halleri, and for all cases,

\section{Amplitud de nicho trófico, superposición de dietas}

Los valores del índice de Smith mostraron un nicho trófico amplio (FT $>0.5)$ en todas las especies en ambas temporadas de estudio. Todas consumieron un número elevado de presas y mostraron una estrategia alimentaria generalista, lo que les permite consumir cualquier tipo de presas disponibles. En el verano se presentaron valores de entre 0.6 y 0.8 , y durante el invierno los valores variaron entre 0.5 y 0.8 (Fig. 3).

El índice de Pianka mostró, en general, valores bajos en la superposición de la dieta entre las especies de peces analizadas. Los valores altos en la superposición de dietas fueron entre especies de lenguados Pleuronectiformes y rayas de la familia Urotrygonidae (Tabla 3). En la temporada cálida se presentaron 6 interacciones con altos valores de superposición de la dieta: juveniles de C. querna con P. margaritatus (0.79), C. querna con S. ovale (0.82), P. margaritatus con $S$. ovale (0.79), U. halleri con U. munda (0.92), U. halleri con $U$. rogersi $(0.86)$ y $U$. munda con $U$. rogersi $(0.95)$. Para la época fría, las superposiciones altas se presentaron en B. leopardinus con $U$. munda (0.77), B. leopardinus con $U$. rogersi (0.77), juveniles de $C$. querna con P. margaritatus (0.82), P. ruscarius con S. russula (0.99), P. ruscarius con $U$. rogersi $(0.70)$, y $U$. munda con $U$. rogersi (0.94). A partir de los valores de la riqueza esperada de presas (Fig. 4), se formaron 3 grupos: (a) dieta con alta riqueza de especies integrada por D. holocanthus, P. woolmani, S. ovale, $P$. margaritatus y $B$. leopardinus; (b) dieta con riqueza intermedia integrada por $P$. ruscarius, $S$. russula y los adultos y jóvenes de C. querna; y (c) dieta con baja riqueza de especies integrada por $U$. halleri, $U$. munda y $U$. rogersi. Las especies que presentaron cambios en la riqueza de especies de sus dietas

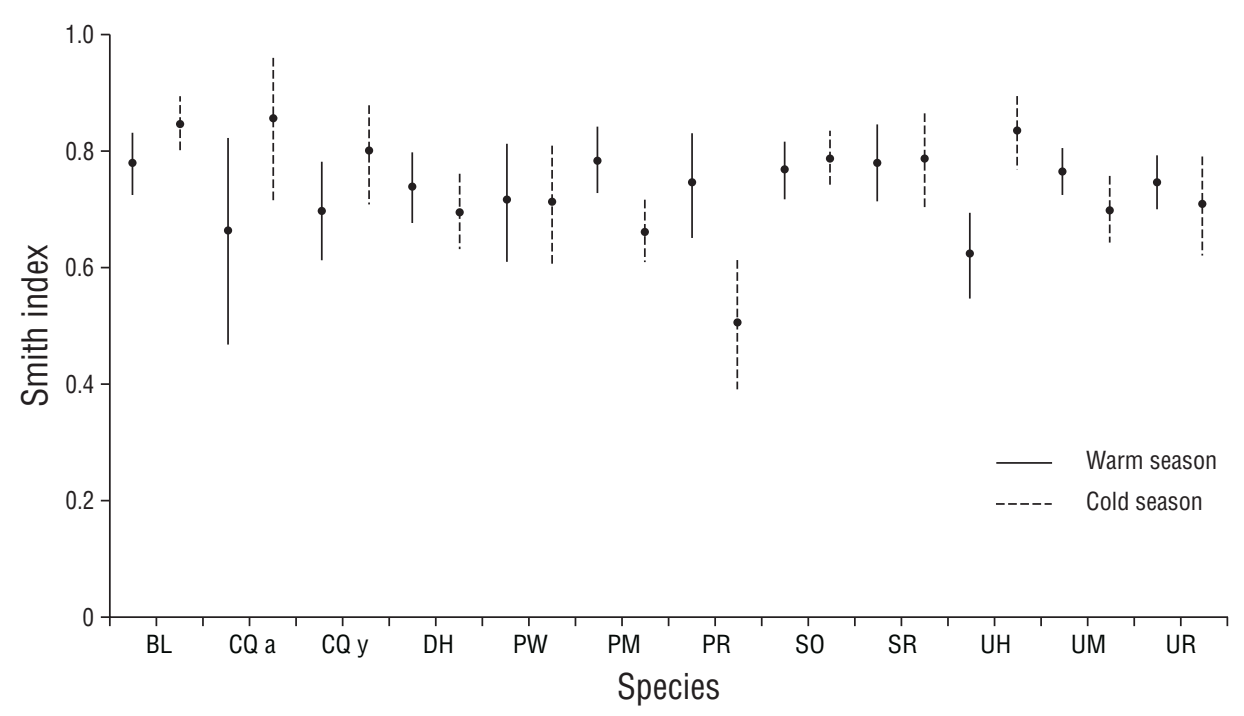

Figure 3. Smith index average values ( $\pm 95 \%$ confidence interval) by species and sampling season (abbreviations of species names are defined in Table 1).

Figura 3. Valores promedio del índice de Smith ( $\pm 95 \%$ intervalos de confianza) por especie y temporada de muestreo (las abreviaturas de los nombres de las especies se definen en la Tabla 1). 
Table 3. Pianka's overlap index values calculated for each pair of demersal fish species and by season. Abbreviations of species names are defined in Table 1. Values in bold are considered significant $(>>0.60)$.

Tabla 3. Valores de superposición de la dieta de acuerdo al índice de Pianka calculados para cada par de especies de peces demersales y por temporada. Las abreviaturas de los nombres de las especies se definen en la Tabla 1 . Los valores en fuente negrita ( $>>0.60)$ se consideran significativos.

\begin{tabular}{|c|c|c|c|c|c|c|c|c|c|c|c|c|}
\hline & BL & CQ a & CQ y & DH & PM & PR & PW & $\mathrm{SO}$ & SR & UH & UM & UR \\
\hline CQ a & 0.06 & $*$ & 0.72 & 0.03 & 0.38 & 0.08 & 0.20 & 0.62 & 0.10 & 0.20 & 0.34 & 0.29 \\
\hline $\mathrm{DH}$ & 0.39 & 0.09 & 0.14 & $*$ & 0.14 & 0.51 & 0.06 & 0.14 & 0.09 & 0.07 & 0.11 & 0.11 \\
\hline PM & 0.06 & 0.64 & 0.82 & 0.16 & $*$ & 0.24 & 0.27 & 0.79 & 0.19 & 0.40 & 0.55 & 0.60 \\
\hline PW & 0.12 & 0.32 & 0.40 & 0.02 & 0.38 & 0.17 & $*$ & 0.50 & 0.11 & 0.08 & 0.15 & 0.18 \\
\hline SO & 0.51 & 0.17 & 0.27 & 0.13 & 0.35 & 0.56 & 0.26 & $*$ & 0.21 & 0.33 & 0.46 & 0.47 \\
\hline SR & 0.29 & 0.07 & 0.03 & 0.25 & 0.09 & 0.97 & 0.06 & 0.60 & $*$ & 0.18 & 0.18 & 0.21 \\
\hline UH & 0.43 & 0.31 & 0.21 & 0.46 & 0.19 & 0.71 & 0.10 & 0.58 & 0.77 & $*$ & 0.92 & 0.86 \\
\hline UM & 0.73 & 0.16 & 0.09 & 0.08 & 0.15 & 0.24 & 0.09 & 0.22 & 0.36 & 0.36 & $*$ & 0.95 \\
\hline
\end{tabular}

the highest richness was observed during the warm period, except in the case of $U$. halleri, for which the highest richness in the diet was observed in the cold period.

The associations between predator species were related to common prey preferences (Fig. 5). Species such as P. woolmani and C. querna (juveniles) preferred consuming fish; on the other hand, C. querna (adults) and P. margaritatus consumed fish, squid, and crabs. Diodon holocanthus consumed crabs and mollusks, and B. leopardinus, $P$. ruscarius, S. russula, S. ovale, U. halleri, U. munda, and U. rogersi consumed shrimp and stomatopods. The associations of species in predator diets showed significant differences between hydroclimatic seasons for $B$. leopardinus $(R=0.519)$, $P$. woolmani $(R=0.382), U$. halleri $(R=0.306), U$. munda $(R=0.321)$, and $U$. rogersi $(R=0.538)$ (global $R=0.231$, $P<0.05)$.

\section{Discussion}

Soft bottoms in the ocean are used as feeding sites by a large variety of fish species, including species associated with rocky bottoms (Flores-Ortega et al. 2010, 2014), because of the large diversity of foraging species, mainly macroinvertebrates (Parrish 1989). Different studies of trophic dynamics in predator communities inhabiting soft-bottom demersal systems have found that the most important prey in the diets are crustaceans and fishes, followed by mollusks, echinoderms, and polychaetes, which together represent almost the entire diet (Navia et al. 2007; Flores-Ortega et al. 2011, 2013; Anastasopoulou et al. 2019).

Abundance and diversity in the soft-bottom benthic macroinvertebrate community in the PCCM show seasonal entre temporadas fueron D. holocanthus, B. leopardinus, $P$. ruscarius y $U$. halleri, y en todos los casos, la mayor riqueza se observó durante el periodo cálido, excepto en el caso de $U$. halleri, para la cual la mayor riqueza en la dieta se encontró en el periodo frío.

La asociación entre las especies de depredadores estuvo relacionada con la preferencia en el consumo común de presas (Fig. 5). Las especies como P. woolmani y C. querna (juveniles) prefirieron consumir peces; en cambio, C. querna (adultos) y $P$. margaritatus fueron consumidores de peces, calamares y cangrejos. Diodon holocanthus fue consumidor de cangrejos y moluscos, y B. leopardinus, $P$. ruscarius, $S$. russula, S. ovale, U. halleri, U. munda y U. rogersi fueron consumidores de camarones y estomatópodos. Se encontró una diferencia significativa en las asociaciones de especies que compusieron la dieta de los depredadores entre estaciones hidroclimáticas para $B$. leopardinus $(R=0.519)$, $P$. woolmani $(R=0.382)$, U. halleri $(R=0.306)$, $U$. munda $(R=0.321)$ y $U$. rogersi $(R=0.538)(R$ global $=0.231$, $P<0.05)$.

\section{Discusión}

Los fondos blandos marinos son utilizados como sitios de alimentación por una gran diversidad de especies de peces, incluso de especies asociadas a fondos rocosos (FloresOrtega et al. 2010, 2014), debido a la existencia de una gran diversidad de especies que forrajean, principalmente macroinvertebrados (Parrish 1989). En diferentes estudios tróficos de las comunidades de depredadores que habitan en sistemas demersales de fondos blandos se ha encontrado que las presas de mayor importancia en la dieta son los crustáceos 


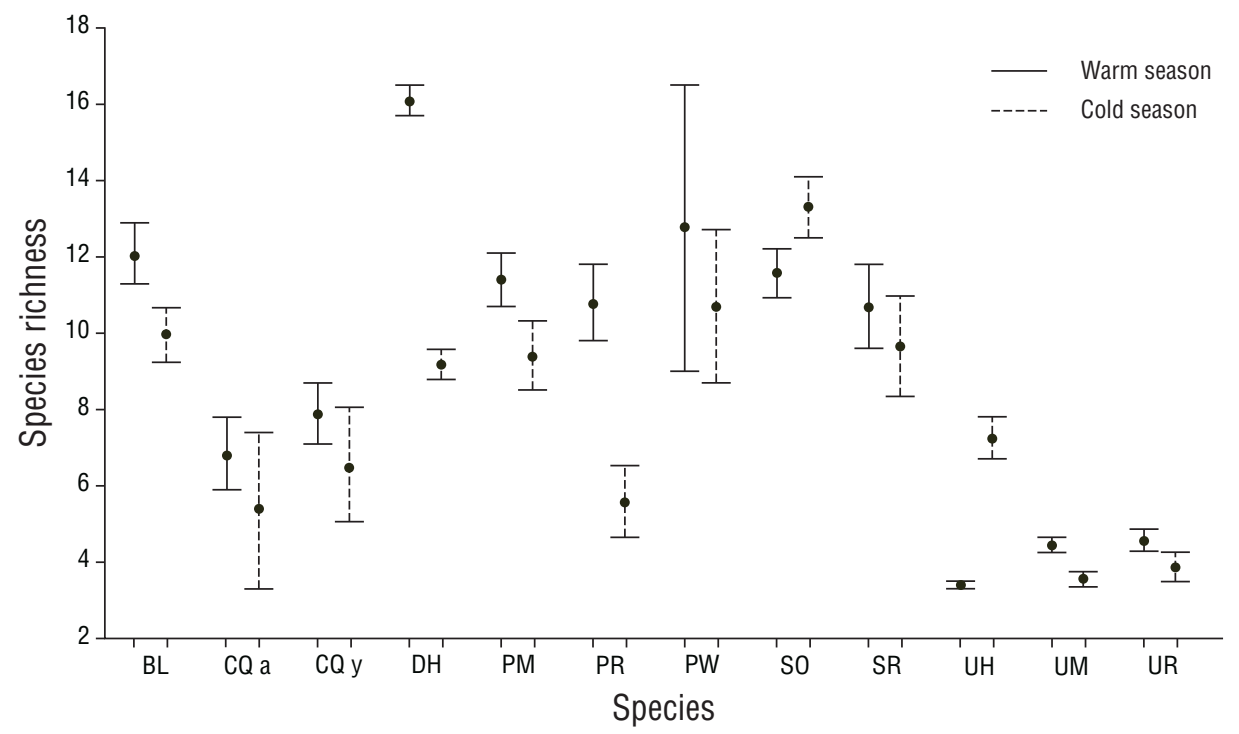

Figure 4. Expected species richness $( \pm 95 \%$ confidence interval) given by the rarefaction curves, with 30 prey for every predator species and every season (abbreviations of species names are defined in Table 1).

Figura 4. Riqueza esperada de especies ( $\pm 95 \%$ intervalos de confianza) dada por las curvas de rarefacción, con 30 presas por especie de depredador y por temporada hidroclimática (las abreviaturas de los nombres de las especies se definen en la Tabla 1).

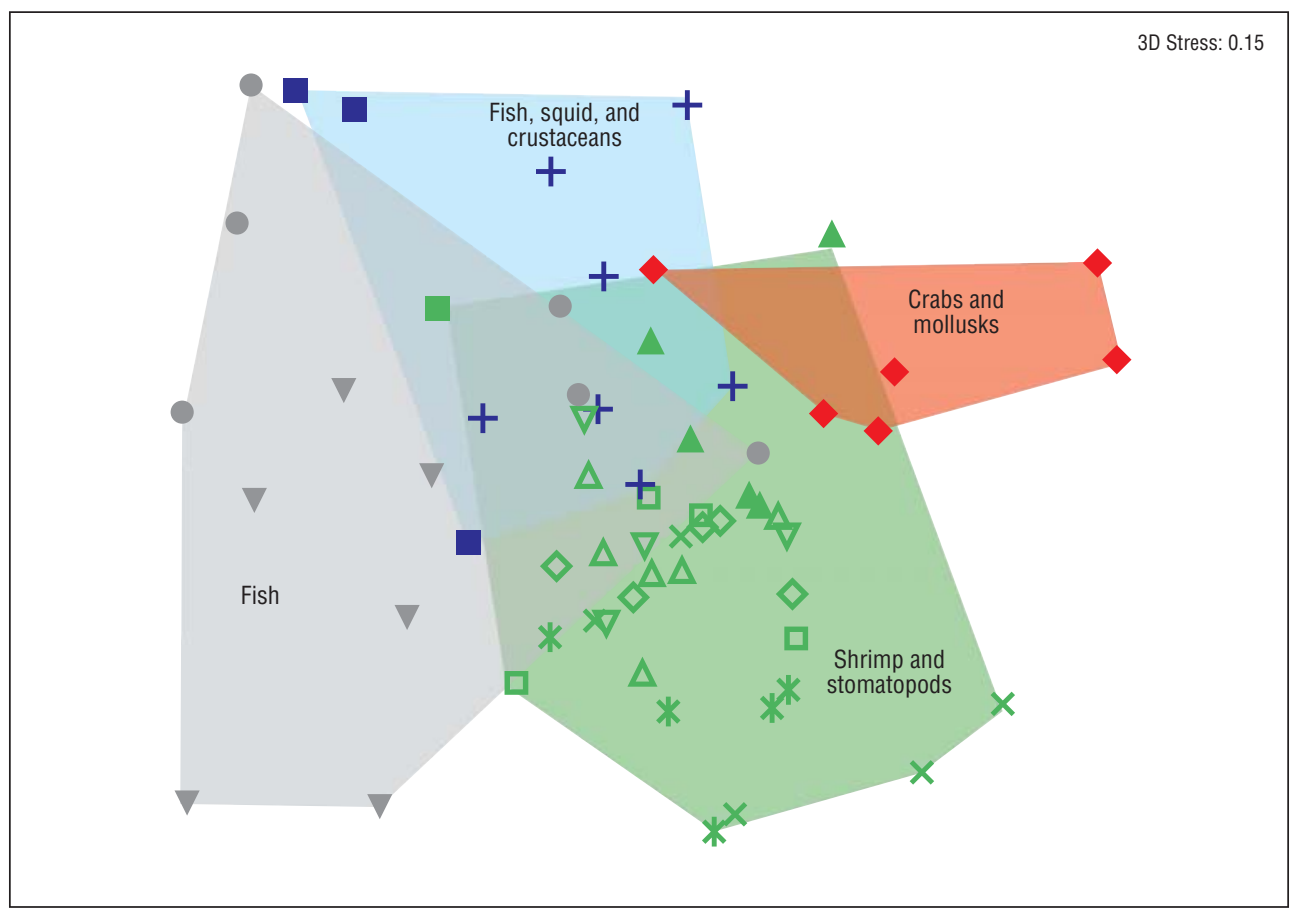

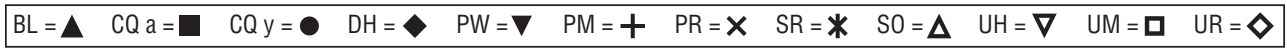

Figure 5. Non-metric multidimensional scaling showing the trophic functional groups for the 11 demersal fish species analyzed. The symbols correspond to each of the fish species (abbreviations defined in Table 1). The colors show the patterns of association of predator species based on prey item similarities ( $\mathrm{red}=$ crabs and mollusks; blue = fish, crustaceans, and squids; gray $=$ fish; green $=$ shrimp and stomatopods).

Figura 5. Escalamiento multidimensional no métrico que muestra los grupos funcionales en las dietas de las 11 especies de peces demersales analizadas. Los símbolos corresponden a cada una de las especies de peces (las abreviaturas se definen en la Tabla 1). Los colores muestran el patrón de asociación de las especies de depredadores con base en la similitud de las presas (rojo = cangrejos y moluscos; azul = peces, crustáceos y calamares; gris = peces; verde = camarones y estomatópodos). 
fluctuations associated with changes in temperature and dissolved oxygen in the deep water mass (González-Sansón et al. 1997, Godínez-Domínguez and González-Sansón 1998, Godínez-Domínguez et al. 2009). However, predators are not affected, because the availability of food resources is, apparently, not limiting, and they simply prey on resources available each season, a behavior of opportunistic predators (Aguilar-Palomino and González-Sansón 2010). The present study showed that $C$. querna exhibits ontogenetic and even seasonal changes in its diet. Changes in the community structure of soft-bottom macrobenthos are reflected in the feeding behavior of predators, which has been reported for similar environments in other parts of the world (Mohanraj and Prabhu 2012). In most demersal fish communities, the process of food partitioning is governed by the size or sex of organisms (Zahorcsak et al. 2000, Link et al. 2002, Moura et al. 2008), and in some cases the temporal variability of resources has direct influence on feeding strategies and habits (Schückel et al. 2011).

Pérez-España et al. (2005) found minimal dietary overlap in the demersal fish community in the PCCM, which is consistent with our results. The analyzed fish species showed a generalist feeding strategy in both seasons. However, in a trophic analysis, Raymundo-Huizar and Chiappa-Carrara (2000) found that, like Diodon histrix, D. holocanthus has a specialized feeding behavior, which could really mean a manifestation of opportunism, feeding on a few prey because of high availability rather than selectivity.

Most demersal fish species in the PCCM show high diversity of prey in their diets and often share basic food categories, so competition for food could be thought of as a potentially important ecological interaction in the trophic dynamics of soft bottoms in the PCCM. However, no evidence of competition was observed given the generalistopportunistic strategy of these species and the dynamics of the community structure of both fishes and invertebrates, and for competition to exist, shared resources have to be limiting (Kidawa and Kowalczyk 2011). Groups such as rays and flatfish, which show high dietary overlap, also show high plasticity by seasonally changing their diet composition to avoid competing for food with other species, regardless of diet richness or trophic niche breadth. This behavior is documented as one of the feeding strategies of demersal fish communities (Lucena et al. 2000, Moura et al. 2008, Donelson et al. 2019).

In demersal communities, fish can partition resources on a spatial level instead of the diet (Le Pape et al. 2013, O'Shea et al. 2013), since their ecological niche range provides the food resources they prefer and need to cover their energy requirements. Habitat partitioning frequently occurs with ontogenetic changes in habitat use (Reis-Filho et al. 2019), whereby adults are spatially segregated from juveniles, but this behavior was not observed in the soft-bottom coastal area of the PCCM, because juveniles and adults showed high co-occurrence in the area. In this study, resource y los peces, y en segundo término las especies de moluscos, equinodermos y poliquetos, y que juntas representan casi la totalidad de la dieta (Navia et al. 2007; Flores-Ortega et al. 2011, 2013; Anastasopoulou et al. 2019).

La abundancia y la diversidad de la comunidad de macroinvertebrados bentónicos de fondos blandos en la CCMP presentan fluctuaciones estacionales asociadas a los cambios en la temperatura y el oxígeno disuelto de la masa de agua de fondo (González-Sansón et al. 1997, GodínezDomínguez y González-Sansón 1998, Godínez-Domínguez et al. 2009). Sin embargo, los depredadores no se ven afectados, ya que la disponibilidad de recursos alimentarios, al parecer, no llega a ser limitante, y simplemente aprovechan los recursos disponibles en cada temporada, un comportamiento de depredadores oportunistas (Aguilar-Palomino y González-Sansón 2010). En este estudio se observó que C. querna presenta cambios ontogénicos, e incluso estacionales, en la dieta. Los cambios en la estructura de la comunidad del macrobentos de fondos blandos se ven reflejados en el comportamiento alimentario de los depredadores, lo cual ha sido reportado para otros ambientes similares en otras partes del mundo (Mohanraj y Prabhu 2012). En la mayoría de las comunidades de peces demersales, el proceso de partición de los recursos alimentarios ocurre de acuerdo a la talla o al sexo de los organismos (Zahorcsak et al. 2000, Link et al. 2002, Moura et al. 2008), y en algunos casos, la variabilidad temporal de los recursos influye directamente en las estrategias y los hábitos alimentarios (Schückel et al. 2011).

Pérez-España et al. (2005) encontró en la comunidad de peces demersales en la CCMP una superposición de las dietas mínima, lo cual concuerda con nuestros resultados. La estrategia alimentaria que presentaron las especies de peces analizadas fue generalista en ambas temporadas de estudio. Sin embargo, en un análisis trófico, Raymundo-Huizar y Chiappa-Carrara (2000) encontraron que D. holocanthus, al igual que Diodon histrix, tiene un comportamiento alimentario especialista, lo cual podría ser una manifestación de oportunismo, al alimentarse de unas pocas presas debido a la gran disponibilidad de éstas, más que por selectividad de esas presas en particular.

La mayoría de especies de peces demersales en la CCMP presentan una alta diversidad de presas en sus dietas y muchas veces comparten categorías alimentarias básicas, por lo que la competencia por alimento podría pensarse como una interacción ecológica potencialmente importante en la dinámica trófica de los fondos blandos en la CCMP. Sin embargo, no se observaron evidencias de competencia gracias a la estrategia generalista-oportunista de las especies y la dinámica de la estructura de la comunidad tanto de peces como de invertebrados, ya que para existir la competencia, los recursos compartidos deben ser limitados (Kidawa y Kowalczyk 2011). Grupos como las rayas y los lenguados, los cuales presentan entre sí altos valores de superposición de la dieta, también muestran una gran plasticidad al cambiar la composición de su dieta estacionalmente para eludir la 
partitioning between demersal predator species was established by the functional groups in the diet, for example, the preference of ray species (Urotrygonidae) for carid shrimp and other crustaceans; the preference of small size flatfish species (Pleuronectiformes) for fish; the preference of large and medium-sized flatfish for fish, crustaceans, and squid; and the preference of diodons (Diodontidae) for mainly crabs, gastropod mollusks, and shrimp. The feeding organization and behavior of a community are associated with factors such as food resource availability, predator preference (Yamamoto and Tominaga 2005, Hajisamae 2009), and physiological aspects such as shape and size of the buccal structure (Barnett et al. 2006, Flores-Ortega et al. 2014). According to Zahorcsak et al. (2000), differences in these factors reduce overlaps in resource use and favor coexistence in soft-bottom fish communities, which could be the case in the PCCM.

English Translation by Claudia Michel-Villalobos.

\section{REFERENCES}

Aguilar-Palomino B, González-Sansón G. 2010. Composición y superposición de dietas en cuatro especies de Diplectrum (Perciformes: Serranidae) en el Pacífico central mexicano. Rev Biol Trop (Int. J. Trop. Biol.). 58(4):1189-1198. https://doi.org/10.15517/rbt.v58i4.5404

Anastasopoulou A, Mytilineou C, Smith CJ, Papadopoulou KN. 2019. Crustacean prey in the diet of fishes from deep waters of the Eastern Ionian Sea. J Mar Biol Assoc UK. 99(1):259-267. https://doi.org/10.1017/s0025315417001977

Barnett A, Bellwood DR, Hoey AS. 2006. Trophic ecomorphology of cardinalfish. Mar Ecol Prog Ser. 322:249-257. https://doi.org/10.3354/meps322249

Bianchi G, Gislason H, Graham K, Hill L, Jin X, Koranteng K, Manickchand-Heileman S, Payá I, Sainsbury K, Sanchez F, et al. 2000. Impact of fishing on size composition and diversity of demersal fish communities. ICES J Mar Sci. 57(3):558-571. https://doi.org/10.1006/jmsc.2000.0727

Carrassón M, Cartes JE. 2002. Trophic relationships in a Mediterranean deep-sea fish community: partition of food resources, dietary overlap and connections within the benthic boundary layer. Mar Ecol Prog Ser. 241:41-55. https://oi.org/10.3354/meps241041

Chao A, Gotelli NJ, Hsieh TC, Sander EL, Ma KH, Colwell RK, Ellison AM. 2014. Rarefaction and extrapolation with Hill numbers: a framework for sampling and estimation in species diversity studies. Ecol Monog. 84(1):45-67. https://doi.org/10.1890/13-0133.1

Clarke KR. 1993. Non-parametric multivariate analyses of changes in community structure. Aust J Ecol. 18(1):117-143. https://doi.org/10.1111/j.1442-9993.1993.tb00438.x

Clarke KR, Warwick RM. 2001. Change in marine communities: An approach to statistical analysis and interpretation. 2nd ed. Plymouth (UK): PRIMER-E. 176 p.

Colwell RK. 2013. EstimateS: Statistical estimation of species richness and shared species from samples. Version9.1. User's Guide and Application. [Storrs (CT)]: [University of Connecticut]; accessed 2016 Jul 17. http://purl.oclc.org/ estimates. competencia por alimento con otras especies, lo anterior independientemente de la riqueza de la dieta o la amplitud del nicho trófico. Este comportamiento está documentado como una de las estrategias alimentarias de la comunidad de peces demersales (Lucena et al. 2000, Moura et al. 2008, Donelson et al. 2019).

En las comunidades demersales, los peces pueden particionar los recursos sobre el eje espacial en lugar de la dieta (Le Pape et al. 2013, O’Shea et al. 2013), ya que en el espacio que utilizan como parte de su nicho ecológico, encuentran los recursos alimentarios que prefieren y cubren sus necesidades energéticas. Una de las maneras más frecuentes de partición del hábitat se da a través de los cambios ontogénicos en el uso del hábitat (Reis-Filho et al. 2019), lo cual segrega espacialmente a adultos de juveniles, pero este comportamiento no fue observado en la zona costera de fondos blandos de la CCMP, ya que los juveniles y los adultos presentaron una alta co-ocurrencia en el área. En este estudio, la partición de los recursos entre las especies de depredadores demersales fue establecida de acuerdo a la formación de grupos funcionales en la dieta, por ejemplo, la preferencia de las especies de rayas (Urotrygonidae) por consumir camarones carídeos y otros crustáceos; la preferencia de especies de lenguados (Pleuronectiformes) de talla pequeña por consumir peces; la preferencia de lenguados de talla mediana y grande por consumir peces, crustáceos y calamares; y la preferencia de los diodones (Diodontidae) por consumir cangrejos, moluscos gasterópodos y camarones, principalmente. La organización y el comportamiento alimentario de una comunidad están relacionados con factores como la disponibilidad de los recursos alimentarios, la preferencia por parte de los depredadores (Yamamoto y Tominaga 2005, Hajisamae 2009) y los aspectos fisiológicos, como la forma y el tamaño de la estructura bucal (Barnett et al. 2006, Flores-Ortega et al. 2014). De acuerdo con Zahorcsak et al. (2000), las diferencias en los factores anteriores reducen la superposición del uso de los recursos y favorecen la coexistencia de la comunidad de peces de fondos blandos, lo cual podría ser el caso de la CCMP.

Dell Q, Griffiths SP, Tonks ML, Rochester WA, Miller MJ, Duggan MA, van der Velde TD, Pillans RD, Coman GJ, Bustamante $\mathrm{RH}$, et al. 2013. Effects of trawling on the diets of common demersal fish by-catch of a tropical prawn trawl fishery. J Fish Biol. 82(3):907-926. https://doi.org/10.1111/jfb.12026

Donelson JM, Sunday JM, Figueira WF, Gaitán-Espitia JD, Hobday AJ, Johnson CR, Leis JM, Ling SD, Marshall D, Pandolfi JM, et al. 2019. Understanding interactions between plasticity, adaptation and range shifts in response to marine environmental change. Phil Trans R Soc B. 374(1768):20180186. https://doi.org/10.1098/rstb.2018.0186

Espinoza M, Clarke TM, Villalobos-Rojas F, Wehrtmann IS. 2013. Diet composition and diel feeding behaviour of the banded guitarfish Zapteryx xyster along the Pacific coast of Costa Rica, Central America. J Fish Biol. 82(1):286-305.

https://doi.org/10.1111/j.1095-8649.2012.03488.x 
Filonov AE, Tereshchenko IE, Monzón CO, González-Ruelas ME, Godínez-Domínguez E. 2000. Variabilidad estacional de los campos de temperatura y salinidad en la zona costera de los estados de Jalisco y Colima, México = Seasonal variability of the temperature and salinity fields in the coastal zone of the states of Jalisco and Colima, Mexico. Cienc Mar. 26(2):303-321. https://doi.org/10.7773/cm.v26i2.577

Flores-Ortega JR, Avila-Castro E, Haro-Preciado HJ, GodínezDomínguez E. 2014. Hábitos alimentarios e interacciones tróficas de Anisotremus interruptus (Pisces: Haemulidae) y Lutjanus argentiventris (Pisces: Lutjanidae) en el Pacífico Central Mexicano $=$ Food habits and trophic interactions of Anisotremus interruptus (Pisces: Haemulidae) and Lutjanus argentiventris (Pisces: Lutjanidae) in the Central Mexican Pacific. Lat Am J Aquat Res. 42(1):276-282.

https://doi.org/10.3856/vol42-issue1-fulltext-24

Flores-Ortega JR, Godínez-Domínguez E, González-Sansón G, Rojo-Vázquez JA, Corgos A, Morales-Jáuregui MY. 2011. Hábitos alimentarios de tres especies de raya (Rajiformes: Urotrygonidae) en el Pacífico central mexicano $=$ Feeding habits of three round stingrays (Rajiformes: Urotrygonidae) in the central Mexican Pacific. Cienc Mar. 37(3):279-292. https://doi.org/10.7773/cm.v37i3.1871

Flores-Ortega JR, Godínez-Domínguez E, González-Sansón G, Rojo-Vázquez JA, López-Prado AC, Morales-Jáuregui MY. 2013. Abundancia, distribución, hábitos alimentarios e interacciones tróficas de cinco especies de lenguados (Pleuronectiformes) en el Pacífico central mexicano = Abundance, distribution, feeding habits and trophic interactions in five flatfish species (Pleuronectiformes) in the Mexican central Pacific. Lat Am J Aquat Res. 41(3):423-439.

Flores-Ortega JR, Godínez-Domínguez E, Rojo-Vázquez JA, Corgos A, Galvan-Piña VH, González-Sansón G. 2010. Interacciones tróficas de las seis especies de peces más abundantes en la pesquería artesanal en dos bahías del Pacífico Central Mexicano. Rev Biol Trop. (Int. J. Trop. Biol.). 58(1):383-397. https://doi.org/10.15517/rbt.v58i1.5217

Godínez-Domínguez E, Freire J. 2003. Information-theoretic approach for selection of spatial and temporal models of community organization. Mar Ecol Prog Ser. 253:17-24. https://doi.org/10.3354/meps253017

Godínez-Domínguez E, Freire J, Franco-Gordo C, GonzálezSansón G. 2009. Decomposing diversity patterns of a softbottom macroinvertebrate community in the tropical eastern Pacific. J Mar Biol Assoc UK. 89(1):31-38. https://doi.org/10.1017/s0025315408002178

Godínez-Domínguez E, González-Sansón G. 1998. Variación en los patrones de distribución batimétrica de la fauna macrobentónica en la plataforma continental de Jalisco y Colima, México $=$ Variation of the bathymetric distribution patterns of the macrobenthic fauna of the continental shelf off Jalisco and Colima, Mexico. Cienc Mar. 24(3):337-351. http://dx.doi.org/10.7773/cm.v24i3.752

Godínez-Domínguez E, Rojo-Vázquez J, Galván-Piña V, AguilarPalomino B. 2000. Changes in the structure of a coastal fish assemblage exploited by a small scale gillnet fishery during an El Niño-La Niña event. Estuar Coast Shelf Sci. 51(6):773-787. https://doi.org/10.1006/ecss.2000.0724

González-Sansón G, Aguilar-Palomino B, Arciniega-Flores J, García de Quevedo-Machaín R, Godínez-Domínguez E, Landa-Jaime V, Mariscal-Romero J, Michel-Morfín JE, Saucedo-Lozano M. 1997. Variación espacial de la abundancia de la fauna de fondos blandos en la plataforma continental de Jalisco y Colima, México (primavera 1995) = Spatial variation of the abundance of the soft-bottom fauna on the continental shelf off Jalisco and Colima, Mexico (Spring 1995). Cienc Mar. 23(1):93-110. http://dx.doi.org/10.7773/cm.v23i1.774

Hajisamae S. 2009. Trophic ecology of bottom fishes assemblage along coastal areas of Thailand. Estuar Coast Shelf Sci. 82(3):503-514. https://doi.org/10.1016/j.ecss.2009.02.010

Hsieh TC, Ma KH, Chao A. 2016. iNEXT: an R package for rarefaction and extrapolation of species diversity (Hill numbers). Met Ecol Evol. 7(12):1451-1456. https://doi.org/10.1111/2041-210x.12613

Kessler WS. 2006. The circulation of the eastern tropical Pacific: a review. Prog Oceanogr. 69(2-4):181-217. https://doi.org/10.1016/j.pocean.2006.03.009

Kidawa D, Kowalczyk R. 2011. The effects of sex, age, season and habitat on diet of the red fox Vulpes vulpes in northeastern Poland. Acta Theriol. 56(3):209-218. https://doi.org/10.1007/s13364-011-0031-3

Krebs CJ. 1999. Ecological Methodology. 2nd ed. Menlo Park (CA): Pearson Ed. 620 p.

Langton RW. 1982. Diet overlap between the Atlantic cod Gadus morhua, silver hake Merluccius bilinearis, and fifteen other northwest Atlantic finfish. Fish B-NOAA. 80(4):745-759.

Le Pape O, Modéran J, Beaunée G, Riera P, Nicolas D, Savoye N, Harmelin-Vivien M, Darnaude AM, Brind'Amour A, Le Bris H, et al. 2013. Sources of organic matter for flatfish juveniles in coastal and estuarine nursery grounds: A meta-analysis for the common sole (Solea solea) in contrasted systems of Western Europe. J Sea Res. 75:85-95. https://doi.org/10.1016/j.seares.2012.05.003

Link JS, Bolles K, Milliken CG. 2002. The feeding ecology of flatfish in the Northwest Atlantic. J Northw Atl Fish Sci. 30:1-17. https://doi.org/10.2960/J.v30.a1

Link JS, Stockhausen WT, Methratta ET. 2005. Food-web theory in marine ecosystems. In: Belgrano A, Scharler UM, Dunne J, Ulanowicz RE. Aquatic Food Webs: An Ecosystem Approach. Oxford (UK): Oxford University Press. p. 98-113. https://doi.org/10.1093/acprof:oso/9780198564836.003.0010

López-Sandoval DC, Lara-Lara JR, Álvarez-Borrego S. 2009a. Phytoplankton production by remote sensing in the region off Cabo Corrientes, Mexico. Hidrobiológica. 19(3):185-192.

López-Sandoval DC, Lara-Lara JR, Lavín MF, Álvarez-Borrego S, Gaxiola-Castro G. 2009b. Primary productivity in the eastern tropical Pacific off Cabo Corrientes, Mexico $=$ Productividad primaria en el Pacífico oriental tropical adyacente a Cabo Corrientes, México. Cienc Mar. 35(2):169-182.

https://doi.org/10.7773/cm.v35i2.1530

Lucena FM, Vaske T, Ellis JR, O'Brien CM. 2000. Seasonal variation in the diets of bluefish, Pomatomus saltatrix (Pomatomidae) and striped weakfish, Cynoscion guatucupa (Sciaenidae) in southern Brazil: implications of food partitioning. Environ Biol Fish. 57(4):423-434. https://doi.org/10.1023/A:1007604424423

Magurran AE. 2004. Measuring Biological Diversity. Oxford (UK): Blackwell Science. 256 p.

Mohanraj T, Prabhu K. 2012. Food habits and diet composition of demersal marine fishes from Gulf of Mannar, Southeast Coast of India. Adv Biol Res. 6(4):159-164.

Moura T, Figueiredo I, Farias I, Serra-Pereira B, Neves A, De Fátima-Borges M, Serrano-Gordo L. 2008. Ontogenetic dietary shift and feeding strategy of Raja undulata Lacepède, 1802 (Chondrichthyes: Rajidae) on the Portuguese continental shelf. Sci Mar. 72(2):311-318.

https://doi.org/10.3989/scimar.2008.72n2311 
Navia AF, Mejía-Falla PA, Giraldo A. 2007. Feeding ecology of elasmobranch fishes in coastal waters of the Colombian Eastern Tropical Pacific. BMC Ecol. 7(1):8. https://doi.org/10.1186/1472-6785-7-8

O'Shea OR, Thums M, van Keulen M, Kempster RM, Meekan MG. 2013. Dietary partitioning by five sympatric species of stingray (Dasyatidae) on coral reefs. J Fish Biol. 82(6):1805-1820. https://doi.org/10.1111/jfb.12104

Parrish JD. 1989. Fish communities of interacting shallow-water habitats in tropical oceanic regions. Mar Ecol Prog Ser. 58:143-160. https://doi.org/10.3354/meps058143

Pérez-España H, Saucedo-Lozano M, Raymundo-Huizar AR. 2005. Trophic ecology of demersal fishes from the pacific shelf off central Mexico. Bull Mar Sci. 77(1):19-31.

Pianka ER. 1973. The structure of lizard communities. Ann Rev Ecol Sys. 4:53-74. https://doi.org/10.1146/annurev.es.04.110173.000413

Rau A, Lewin WC, Zettler ML, Gogina M, von Dorrien C. 2019. Abiotic and biotic drivers of flatfish abundance within distinct demersal fish assemblages in a brackish ecosystem (western Baltic Sea). Estuar Coast Shelf Sci. 220:38-47. https://doi.org/10.1016/j.ecss.2019.02.035

Raymundo-Huizar AR, Chiappa-Carrara X. 2000. Hábitos alimentarios de Diodon histryx y Diodon holocanthus (Pisces: Diodontidae) en las costas de Jalisco y Colima, México. Bol Cent Invest Biol. 34:181-210.

$\mathrm{R}$ Core Team. 2019. R: A language and environment for statistical computing. Vienna (Austria): R Foundation for Statistical Computing; accessed 2020 Jan 18. https:// www.R-project.org/.

Reis-Filho JA, Schmid K, Harvey ES, Giarrizzo T. 2019. Coastal fish assemblages reflect marine habitat connectivity and ontogenetic shifts in an estuary-bay-continental shelf gradient. Mar Envir Res. 148:57-66. https://doi.org/10.1016/j.marenvres.2019.05.004

Ross ST. 1986. Resource partitioning in fish assemblages: A review of field studies. Copeia. 1986(2):352-388. https://doi.org/10.2307/1444996

Ruiz-Rodríguez T, Vázquez-Bader AR, Gracia-Gasca A. 2013. Asociaciones de megacrustáceos epibentónicos en la Sonda de Campeche, golfo de México. Rev Mex Biodivers. 84(1):280-290. https://doi.org/10.7550/rmb.27685

Schückel S, Sell A, Kröncke I, Reiss H. 2011. Diet composition and resource partitioning in two small flatfish species in the German Bight. J Sea Res. 66(3):195-204. https://doi.org/10.1016/j.seares.2011.06.003

Thrush SF, Whitlatch RB, Pridmore RD, Hewitt JE, Cummings VJ, Wilkinson MR.1996. Scale-dependent recolonization: The role of sediment stability in a dynamic sandflat habitat. Ecology. 77(8):2472-2487. https://doi.org/10.2307/2265747

Yamamoto M, Tominaga O. 2005. Feeding ecology of dominant demersal fish species Favonigobius gymnauchen, Repoтucenus spp. and Tarphops oligolepis at a sandy beach where larval Japanese flounder settle in the Seto Inland Sea, Japan. Fish Sci. 71(6):1332-1340. https://doi.org/10.1111/j.1444-2906.2005.01099.x

Zahorcsak P, Silvano RAM, Sazima I. 2000. Feeding biology of a guild of benthivorous fishes in a sandy shore on south-eastern Brazilian coast. Rev Brasil Biol. 60(3):511-518. https://doi.org/10.1590/s0034-71082000000300016

Received October 2019, accepted May 2020. 